\title{
Assessment of Feeding Behavior of the Zoo-Housed Lesser Anteater (Tamandua tetradactyla) and Nutritional Values of Natural Prey
}

\author{
Valentín Zárate ${ }^{1,2,3}{ }^{\mathbb{D}}$, Jesica R. Mufari ${ }^{1,2}$, Lucía G. Abalos Luna ${ }^{4}$, Daniel P. Villarreal ${ }^{5}$ and Juan M. Busso ${ }^{1,2,3, * \mathbb{D}}$ \\ 1 Instituto de Ciencia y Tecnología de los Alimentos, Facultad de Ciencias Exactas, \\ Físicas y Naturales (FCEFyN) - Universidad Nacional de Córdoba (UNC), Av. Vélez Sarsfield 1611, \\ Córdoba X5016GCA, Argentina; valentinzarateee@gmail.com (V.Z.); romi_mufari@hotmail.com (J.R.M.) \\ 2 Instituto de Investigaciones Biológicas y Tecnológicas, Consejo Nacional de Investigaciones Científicas y \\ Técnicas (CONICET)-UNC, Av. Vélez Sarsfield 1611, Córdoba X5016GCA, Argentina \\ 3 Laboratorio de Técnicas No Invasivas, CONICET-Parque de la Biodiversidad (ex Jardín Zoológico Córdoba), \\ Rondeau 798, Córdoba X5000AVP, Argentina \\ 4 Carrera de Veterinaria, Facultad de Ciencias Agropecuarias, Universidad Católica de Córdoba, \\ Av. Armada Argentina 3555, Córdoba X5016DHK, Argentina; luciaabalosluna@gmail.com \\ 5 Parque de la Biodiversidad (ex Jardín Zoológico Córdoba), Rondeau 798, Córdoba X5000AVP, Argentina; \\ danielvillarreal1@hotmail.com \\ * Correspondence: jmbusso@conicet.gov.ar; Tel.: +54-9-351-6711746
}

Citation: Zárate, V.; Mufari, J.R.; Abalos Luna, L.G.; Villarreal, D.P.; Busso, J.M. Assessment of Feeding Behavior of the Zoo-Housed Lesser Anteater (Tamandua tetradactyla) and Nutritional Values of Natural Prey. J. Zool. Bot. Gard. 2022, 3, 19-31. https://doi.org/10.3390/jzbg3010002 Academic Editor: Steven Monfort

Received: 27 October 2021 Accepted: 27 December 2021 Published: 5 January 2022

Publisher's Note: MDPI stays neutral with regard to jurisdictional claims in published maps and institutional affiliations.

Copyright: (C) 2022 by the authors. Licensee MDPI, Basel, Switzerland. This article is an open access article distributed under the terms and conditions of the Creative Commons Attribution (CC BY) license (https:// creativecommons.org/licenses/by/ $4.0 /)$.

\begin{abstract}
Very little information is available to zoo managers on the nutritional preferences of the lesser anteater, a highly specialized predator. By studying lesser anteater feeding behavior, we expect to contribute to improved management decisions and individual welfare experiences. We studied the response of zoo-housed lesser anteaters $(n=7)$ to feeders with live ants (Acromyrmex lundi) and termites (Cortaritermes fulviceps), and we also evaluated the nutritional values of these prey. We individually evaluated each lesser anteater (3 sessions), recording activities by camera. We ground insect samples into a coarse meal and evaluated in vitro biochemical parameters (humidity, lipids proteins, ash, and carbohydrates). Lesser anteaters spent more time with termites than with ants and consumed more termites. Ant meal presented a higher protein and lipid content than termite meal ( $35.28 \pm 0.18 \%$ vs. $18.19 \pm 0.34 \%$ and $16.95 \pm 0.13 \%$ vs. $6.54 \pm 0.31 \%$, respectively), and carbohydrate digestibility was higher in termites. These findings indicate an association between the level of insect consumption and nutritional and digestibility values. This is the first exploration of lesser anteater responses to the presence of social insects in feeders and may serve to guide the study of food preferences in captivity.
\end{abstract}

Keywords: xenarthra; mymercophagidae; diet; live feed; insectivorous; animal welfare

\section{Introduction}

The lesser anteater is a highly specialized predator subsisting almost exclusively on a diet of ants and termites [1]. In the wild, the lesser anteater behaves as an individualistic predator and is nocturnal to crepuscular-diurnal [2,3], actively searching for prey mainly by using its developed sense of smell [1,4]. Several studies have reported that lesser anteaters consume a large variety of ants and termites [5,6]. However, nutritional assessments of lesser anteaters' natural prey are still lacking. We are aware of only one study in which Oyarzun et al. [7] conducted a nutritional assessment of colonies of arboreal termites consumed by this species in the wild.

The lesser anteater occurs in the north and center of South America, reaching as far south as Córdoba, Argentina [1,8]. The lesser anteater is listed as "threatened" in Córdoba, "near threatened" in Argentina, and "of least concern" by the International Union for Conservation of Nature (IUCN) [9-11]. Often injured or vulnerable lesser anteaters are 
rescued and spend time in zoos until the zoo authorities decide whether to relocate them or place them in a conservation program; this is true for all rescued lesser anteaters in Córdoba and other cities in Argentina (personal observation; Daniel Villarreal; personal communication Mariella Superina). It is rarely possible to provide zoo-housed animals with what they would typically eat in the wild [12], and the restricted feeding and foraging opportunities are a potential source of stress [13]. Although there are several formulas for feeding lesser anteaters in zoo environments, usually based on dog or cat food as the principal ingredient [14], the specific dietary requirements of the species and information on the consumption and energy intake of the different dietary items are lacking, including for live feed [15-17]. Thus, we consider that an assessment of the response of lesser anteaters to natural food, such as insects, may provide opportunities to improve the feeding regime in captivity. Furthermore, an assessment of the nutritional value of the provided insects will not only be useful for improving the ex situ conservation management of this species but can also be used to underscore food-based enrichment proposals for these animals in zoos or rescue centers $[18,19]$.

In this study, we focused on one ant species (Acromyrmex lundi) and one termite species (Cortaritermes fulviceps). Acromyrmex lundi and C. fulviceps build similar-looking nest structures as a primary defense strategy in the wild [20,21]. This similar defense strategy and the similar size of these social insects, taken in conjunction with the morphological and behavioral predator adaptations of lesser anteaters (e.g., thick skin and short forefoot, respectively), would appear to indicate that $A$. lundi and C. fulviceps are similarly vulnerable to this predator. In contrast, the release of volatile compounds (pheromones) as a communication strategy differs widely between the two insect species and can act at an interspecific level, for example, attracting potential predators [22,23]. Taking into account the olfactory capacity of lesser anteaters, these differences may affect the detectability of insects. Further possible factors affecting the choice of food are its nutritional value and digestibility. Digestibility can vary among insects, depending on the characteristics of the integument (composed largely of proteins and carbohydrates that are difficult to degrade [22,24]); in vitro protein and carbohydrate digestibility may be an indicator of in vivo digestibility. Furthermore, the proportion of ash (total minerals), proteins, lipids, and energy varies among insects [25]. Thus, the study of feeding behavior responses to these social insects may be useful for understanding predator-prey interaction. Information on the nutritional value of food stimuli can contribute to a more complete understanding of feeding behaviors and support better decision making in the management of wild and zoo-housed lesser anteaters.

We hypothesized that the characteristics of $A$. lundi and C. fulviceps affect the feeding behavior of lesser anteaters in captivity. According to the optimal foraging theory [26], foods with the highest profitability (energy intake/handling times) are preferred. Therefore, we expect that, if handling times are similar, lesser anteaters will prefer the insect that provides the highest nutritional values (energy). Our objectives were to: A-evaluate the activity pattern and amounts of ants (A. lundi) and termites (C. fulviceps) consumed by lesser anteaters under laboratory conditions, and the timing of consumption of ants (A. lundi) and termites (C. fulviceps) (Study 1); B-measure humidity, proteins, ash, lipids, and the protein and carbohydrate digestibility in vitro of the insects offered as food stimuli to infer their nutritional value (Study 2).

We also consider that this study contributes to the welfare of zoo-housed lesser anteaters. Studies of animal behavior serve as a diagnostic tool in relation to animal welfare. Practitioners frequently wonder what animal behavior tells them about how their environment (light, temperature, food, etc.) affects their welfare [27]. We have studied several lesser anteaters housed at Córdoba Zoo (Argentina) in terms of their behavioral response to food-based environmental enrichment [18], natural and abnormal behavioral repertoires, and associated levels of adrenocortical activity [28], and began to explore space use and behavioral response to zoo visitors [29]. We found that lesser anteaters in captivity exhibited higher body weight values than animals in the wild [1,14], potential health risk, 
and thus a negative state of individual welfare owing to erroneous nutritional management. Thus, exploring the feeding behavior of zoo-housed lesser anteaters' response to natural diet items may be a first approach to detecting possible food choices leading to an improvement in their nutrition, a main factor in the "Five Domain Model" to assess animal welfare [30].

\section{Materials and Methods}

\subsection{Subjects, Enclosures, and Management}

We studied adult lesser anteaters $\left(\mathrm{N}=7,4\right.$ o and $\left.3 \sigma^{7}\right)$ housed in individual contiguous enclosures of similar dimensions at Córdoba Zoo ( $31^{\circ} 12.32^{\prime} \mathrm{S}, 64^{\circ} 16.84^{\prime} \mathrm{W}$, Argentina).

Enclosures were designed following housing recommendations for the species [31] Following Eguizábal et al. [28], lesser anteaters were housed individually in contiguous similar-sized enclosures (approximately $38 \mathrm{~m}^{2}$ ), and each individual had at least one individual of the opposite sex as a neighbor (Figure 1). Following Superina et al. [31], enclosures contained a wooden shelter, plastic feeders, and a watering trough, several climbing structures (i.e., logs and wire roof), plants, soil and wood substrate, and wire gates between contiguous enclosures. Each lesser anteater was housed under natural temperature, humidity, and photoperiod.

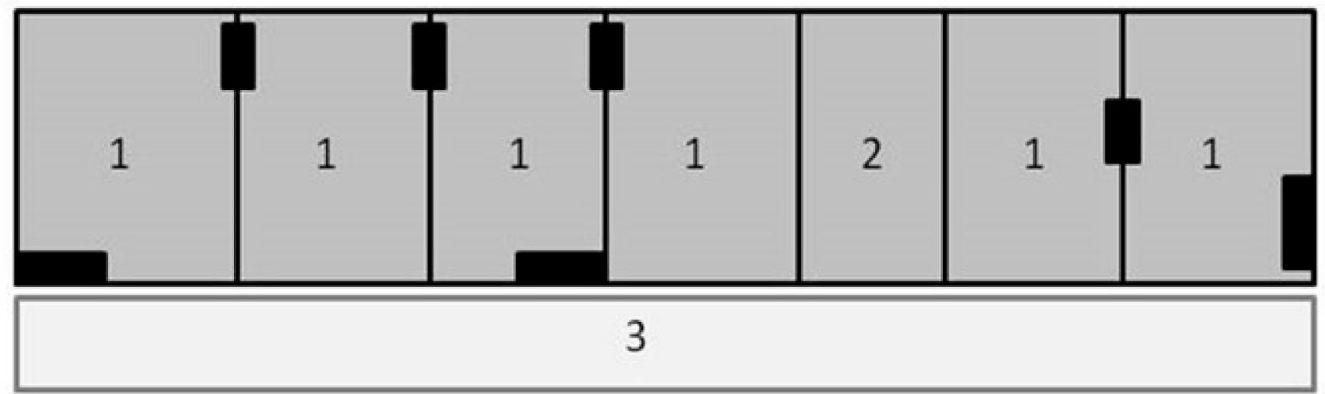

Figure 1. Top view of lesser anteater enclosures and laboratory: 1 represents the enclosures where the individuals were kept; 2 represents the laboratory in which an area was conditioned (evaluation room) to carry out the behavioral evaluations, and 3 represents the public view. Wire gates (smaller black rectangles) connecting enclosures and glass gates (larger black rectangles) to enter the enclosures are shown. There was an enclosure that housed 2 lesser anteaters, a mother and her sub-adult offspring.

Briefly, as in previous studies [18,28], the diet consisted of a semi-liquid shake containing lactose-reduced whole powdered milk (La Serenísima ${ }^{\circledR}$, Buenos Aires, Argentina, $15 \%$ of total dry weight), baby cereal (Nestum ${ }^{\circledR}$, Nestlé, Villa Nueva, Córdoba, Argentina, 14\%), balanced puppy feed (Eukanuba ${ }^{\circledR}$ Small Breed, Buenos Aires, Argentina, 71\%), drinking water (until reaching a semi-liquid consistency, 400-600 mL) and vitamin K (3 mg). The offered quantity varied (700-900 mL) depending on the energetic need of each lesser anteater, which was calculated following Dierenfeld and Graffam [32]. Following the same methodologies and calculation applied in the present study, the nutritional analyses of the zoo-balanced diet provided values of $(\%)$ : humidity $=76.9$, lipids $=5.1$, proteins $=6.1$, ash $=1.4$, and carbohydrates = 10.5; samples of zoo-balanced diet provided $1.12 \mathrm{kcal} / \mathrm{g}$. This assessment is periodically performed as a quality control within the institutions involved in our research activities. Values are from the post-doctoral fellowship work of J.R.M. (under supervision of Dr. J.M.B. and Dr. A. López during 2017-2019; unpublished data). Food was offered to each individual in three $200 \mathrm{~mL}$ plastic cups placed on climbing structures (i.e., logs and wire roof) and in a larger feeder at ground level. We also offered food-based environmental enrichment on a weekly basis: fruits, honey, ants (Camponotus rufipes, Pheidole sp. and in greater quantity A. lundi), and occasionally termites (C. fulviceps). Since all lesser anteaters in the study were already familiar with the food types administered, we assumed there would be no expressions of neophobia. Following Córdoba Zoo routine management, the body weight of the lesser anteaters was recorded on a monthly 
basis in a laboratory adjacent to the enclosures; the animals were, therefore, familiar with being moved from the enclosures to the laboratory, where the evaluation room for behavioral research was located. Daily cleaning routines of enclosures were performed between 9:00 and 12:00 by zookeepers. Food and water were supplied in plastic feeders (the same cups indicated above) located in hanging logs once a day, at approximately 12:00.

\subsection{Procedures to Include Lesser Anteaters in Study 1}

Two additional assessments were performed prior to commencing the main study (Study 1). Firstly, in order to reduce the influence of the evaluation room stimuli on the lesser anteaters, we exposed them individually to the novel environment $(30 \mathrm{~min}$ sessions, $n=3$, during November 2017; see Supplementary Materials: novel environmental evaluation). Based on this assessment, the evaluation room did not negatively affect the exploratory behavior of the lesser anteaters. Secondly, we assessed lesser anteater's response to odors in order to test whether or not individuals were able to detect odor stimuli (see Supplementary Materials: odor discrimination evaluation). Our findings clearly indicated that all the evaluated lesser anteaters reacted to odor stimuli and showed olfactory discrimination, as a consequence of which they were all included in Study 1. We furthermore monitored respiratory frequency, taking this as a simple indicator of reaction to the environment. Lesser anteaters showed an increment in respiratory frequency only during the novel environment evaluation (the first time they were exposed to the evaluation room); this reaction was not evident later (see Supplementary Materials: monitoring of respiratory frequency during the evaluations).

\subsection{Study 1: Objective 1}

\subsubsection{Evaluation Room}

We prepared an area of the laboratory to perform the behavioral evaluations on lesser anteaters. The area $(3 \times 2 \mathrm{~m}$ and $2.5 \mathrm{~m}$ high) had four homogeneous walls, a cement floor, and a single entrance through a door. We used air conditioning to maintain the temperature at $24.0 \pm 1.1^{\circ} \mathrm{C}$, similar to that measured inside the enclosures $\left(24.5 \pm 1.4^{\circ} \mathrm{C}\right)$. We illuminated the room with artificial light (single lamp placed centrally on the ceiling) (Figure 2a).

(a)

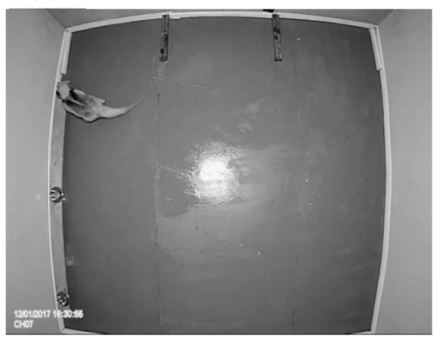

(b)

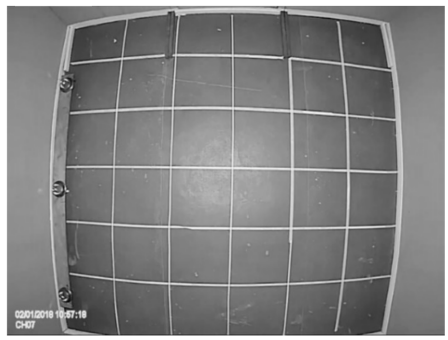

(c)

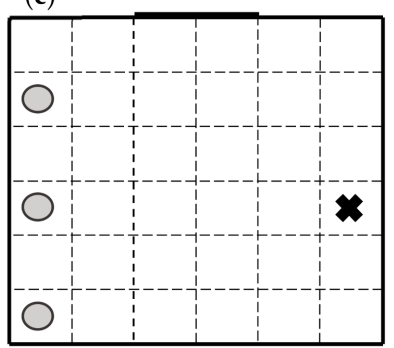

Figure 2. Evaluation room used to study lesser anteaters' behavior in response to termites and ants: (a) a video image of the room taken with the camera used to video record activities during the behavioral evaluation, the feeders, and an anteater in contact with one feeder. The position of each food type was randomized during each session. The camera was located on the ceiling; (b) prior to the first behavioral evaluation, we delimited zones in the room with adhesive tape to record activities on the videos. Tapes were removed before performing the evaluations; (c) a diagram of the evaluation room based on lines on the floor. Each video was filtered by this diagram on the monitor, and we analyzed the activities of lesser anteater. " $x$ " means the space where the lesser anteater was released with its four legs contacting the ground in the evaluation room, and "circles" means feeders.

\subsubsection{Behavioral Evaluations: Anteater Response to Food Stimuli}

We exposed the lesser anteaters individually and randomly to the evaluation room between 17:00 and 20:00 when they are usually active [28]. Before the entrance of each animal, we cleaned the room using water with sodium hypochlorite $(40-60 \mathrm{~g} / \mathrm{L})$ at $0.001 \%$. 
Moving each lesser anteater from its enclosure to the evaluation room took $<1 \mathrm{~min}$, and the same person performed this task, holding the animal by the tail as keepers usually do to check body weight.

We evaluated the activities of the lesser anteaters in the presence of 3 feeders in the evaluation room. A feeder with live ants, another with live termites (each food stimuli; $1.07 \pm 0.01 \mathrm{~g} /$ feeder), and an empty feeder (as a control of those feeders with insects). Since A. lundi ants do not present differences between soldier and worker castes, we used only mature workers. In the case of $C$. fulviceps termites, the caste proportions were: soldier $/ 0.13$, workers $/ 0.25$, and immature $/ 0.62$. All insects were collected together with the substrate from their nests and kept in plastic containers until they were presented to the lesser anteaters; all insects used during evaluations were alive. We separated the insects from the substrate of their nests $6 \mathrm{~h}$ prior to each evaluation and placed them in sterile cups $(200 \mathrm{~mL})$ until the evaluation. A. lundi individuals were collected from nests located in Córdoba city $\left(31^{\circ} 25^{\prime} 42.5^{\prime \prime} \mathrm{S}, 64^{\circ} 10^{\prime} 25.4^{\prime \prime} \mathrm{W}\right)$ and C. fulviceps in Pocho Department, located approximately $265 \mathrm{~km}$ from Córdoba city $\left(31^{\circ} 20^{\prime} 55.1^{\prime \prime} \mathrm{S} 65^{\circ} 07^{\prime} 44.5^{\prime \prime} \mathrm{W}\right)$. Before presenting ants and termites, we washed all feeders (metal dishes $10 \mathrm{~cm}$ in diameter and $5 \mathrm{~cm}$ deep) with water and dried them with paper prior to the arrival of each lesser anteater. In order to prevent insects from escaping, we impregnated the edges of all the feeders with silicone $(100 \%)$. We individually exposed the lesser anteaters to 3 feeders, one with ants, another with termites, and one empty (control). The daily order of evaluation of the lesser anteaters was random, as was the location of the insects in the feeders. We evaluated lesser anteaters 3 times during a $10 \mathrm{~min}$ session (December 2017), exposing each individual to one session per day. At the end of each session, we recovered the remaining insects from the feeders in order to quantify the consumption. When each lesser anteater was released back into its enclosure, normal activity resumed, presumably indicating no post-evaluation discomfort.

\subsubsection{Methodology and Variables for Behavioral Evaluations}

We used the focal sampling method for all lesser anteaters and the continuous recording rule for both evaluations. Figure $2 b, c$ illustrate the designated zones of the evaluation room for video recording activities that mostly characterized the expression of feeding behavior. We divided the room into 36 squares of $50 \times 50 \mathrm{~cm}$ (more details are available in Supplementary Data). We analyzed the followings activities through videos recorded on a DVR (HIKVISION Turbo HD DVR-DS 7200 Series, Binjiang, China):

- Ambulatory latency (s): time elapsed between placing the lesser anteater in the evaluation room with its four legs contacting the ground (see, for example, the cross in Figure 2a) and the complete head leaving the first square;

- Visits to the feeders (counting): number of times the lesser anteater visited each feeder, considering a visit to be when the animal entered the square and contacted the feeder. On each session, we also registered which feeder lesser anteaters visited first;

- Visit duration at feeders (s): time spent by each lesser anteater inside the square where the feeders were located, considering a visit to be each time the lesser anteater entered the square and contacted the feeder. We calculated the total visit duration per feeder. Considering the maximal number of visits in each feeder, we also calculated the visit duration per visit in order to characterize visits change over the $10 \mathrm{~min}$ of this trial;

- Consumption of insects (g): quantity of insects consumed by each lesser anteater in each session. We calculated this variable based on the difference between the weight of the insect meal before and after the evaluation.

\subsection{Study 2: Objective 2}

\subsubsection{Preparation of Insects and Nutritional Assessment}

During November 2017, we collected ants and termites for the nutritional assessments from the same locations and in the same way indicated for the feeding behavior study (see Section 2.3.2). Samples of live insects were frozen ( $5 \mathrm{~g}$; without nest organic material) for $1 \mathrm{~h}$ in a freezer, dried at $100-105^{\circ} \mathrm{C}$ in a forced circulation oven for $24 \mathrm{~h}$, and finally ground 
to obtain a course meal. We did not dry samples used for humidity content assessment. The number of samples/insects evaluated for all variables $=2$, except for ash $(n=1)$. We analyzed the samples according to the methods recommended by the AOAC [33]. Variables (\%): (1) humidity content by the indirect method of oven drying at $100{ }^{\circ} \mathrm{C}$ (AOAC 934.01); (2) free total fat content (lipids) by the gravimetric method after extraction with Soxhlet using n-hexane as solvent (AOAC 920.39); (3) crude protein content (proteins) by the Kjeldahl method (AOAC 984.13), using a general conversion factor of 6.25 ; (4) ash content by muffling at $550{ }^{\circ} \mathrm{C}$ (AOAC 923.03); and (5) carbohydrate content calculated by the difference between $100 \%$ and values of $1-4$ (humidity + lipids + proteins + ash).

We performed all measurements of centesimal composition in triplicate and expressed them in $\mathrm{g} / 100 \mathrm{~g}$ of sample on a wet basis. From the centesimal composition values, we were able to calculate the caloric content $(\mathrm{kcal} / \mathrm{g})$ of the insects, taking the individual contributions of each variable [34].

\subsubsection{In Vitro Protein and Carbohydrate Digestibility}

Due to the decision of the zoo administration, we were not allowed to replace the routine diet with social insects during this study. We were only able to measure the digestibility parameter by in vitro tests [35-37]. Since the digestive characteristics of lesser anteaters' tract are poorly known, we used a technique that mimics the general digestive process of monogastric mammals. We measured the protein digestibility according to the technique of Dierick et al. [38], with modifications. We incubated $400 \mathrm{mg}$ of each insect sample together with $20 \mathrm{~mL}$ of $0.075 \mathrm{M} \mathrm{HCl}, 20 \mathrm{mg}$ of pepsin (P7000, Sigma-Aldrich ${ }^{\circledR}$, Burlington, MA, USA), with the $\mathrm{pH}$ adjusted to 2 , in a thermostatic bath at $37.5{ }^{\circ} \mathrm{C}$ for $30 \mathrm{~min}$ after which we added $25 \mathrm{~mL}$ of $0.2 \mathrm{M}$ phosphate buffer $(\mathrm{pH} 7.5)$ and $20 \mathrm{mg}$ of

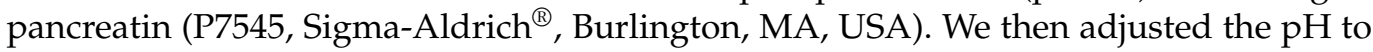
7.5 and incubated the sample for a further $60 \mathrm{~min}$ under the conditions described above. At the end of the second incubation period, we took $5 \mathrm{~mL}$ of the digested extract and added $5 \mathrm{~mL}$ of trichloroacetic acid (TCA) at $36 \% w / v$ to precipitate the undigested proteins and enzymes. After centrifugation at $1100 \times g$, we measured the total nitrogen content in the supernatant by the Kjeldahl method 984.13 [33] and the content of total sugars by the anthrone method [39]. Results are expressed as digestibility (\%) on a dry basis.

\subsection{Statistical Analyses}

We analyzed ambulatory latency by one-way analysis of variance with the lesser anteaters as the source of variation. Since the variable was not normally distributed according to the Shapiro-Wilks test, we transformed the data $(\log 10)$ and then applied a posteriori Fisher LSD test. For the analysis of visit duration over time, the fixed factor was the number of visits (8 levels), and the lesser anteater was the random factor; the analysis was partitioned by feeder (control, ants, or termites). This analysis was performed to address the following questions: how did the lesser anteaters behave during the $10 \mathrm{~min}$ : did they first eat all the termites and only then go on to the ants? Or did they constantly walk around and sample all feeders regularly (this could perhaps reflect a typical foraging strategy of anteaters)? How did the duration of the visits change over time during the $10 \mathrm{~min}$ ? For feeder visits, visit duration, and insect consumption, we used a statistical analysis of general and mixed linear models as indicated by Mangeaud and Videla [40] for food preference tests. The feeder was the fixed factor (3 levels), and the lesser anteater was the random factor. We applied the LSD Fisher test. Due to the low number of samples, we did not perform statistical analyses for the nutritional assessments.

We performed all the analyses using InfoStat [41]. We expressed results as mean \pm SEM, with a significance level of $5 \%$ for all tests. We tested normality of data and homogeneity of variance by the Shapiro-Wilks and Levene methods, respectively. 


\section{Results}

\subsection{Study 1: Objective 1}

We detected no differences in ambulatory latency among the lesser anteaters $\left(\mathrm{F}_{6,13}=1.56\right.$, $p=0.2346$ ). Ambulatory latency was $5.45 \pm 0.73 \mathrm{~s}$. In the three sessions, the lesser anteaters visited the feeders with ants $3.05 \pm 0.32$ times, the feeder with termites $4.10 \pm 0.49$ times, and the feeder without insects (control) $3.65 \pm 0.49$ times $\left(\mathrm{F}_{2,51}=2.27, p=0.1138\right)$. The lesser anteaters first visited the feeder with termites more times (13 out of 21) than the feeder with ants ( 6 out of 21); the feeder without insects was visited 2 times out of 21 . We detected differences in the duration of each visit to the feeders $\left(F_{2,51}=11.12, p=0.0001\right)$. The average total visit duration at each feeder was termites $>$ ants $=$ control $(88.40 \pm 15.83 \mathrm{~s}$, $52.55 \pm 5.88 \mathrm{~s} 29.30 \pm 2.95 \mathrm{~s}$, respectively). In Figure 3, we show the temporal pattern of visits for each feeder. Within each feeder, the statistical differences were: control $\mathrm{F}_{7,64}=19.12$, $p<0.0001$, ants $\mathrm{F}_{7,55}=41.38, p<0.0001$, and termites $\mathrm{F}_{7,72}=133.03, p<0.0001$.

(a)

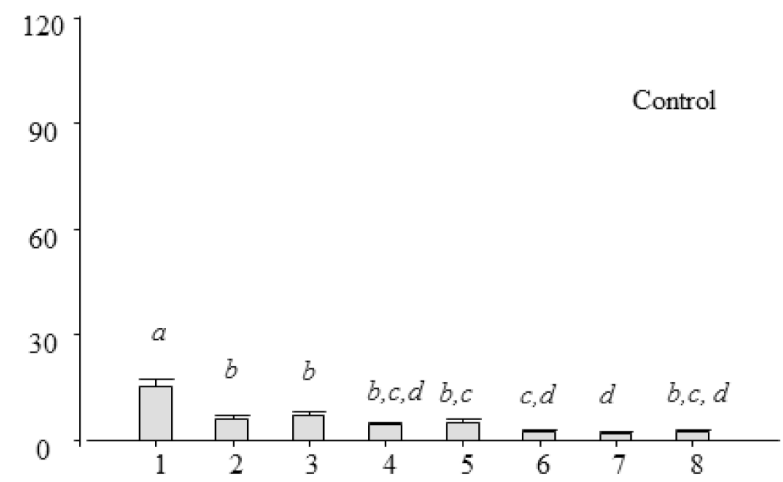

(b)

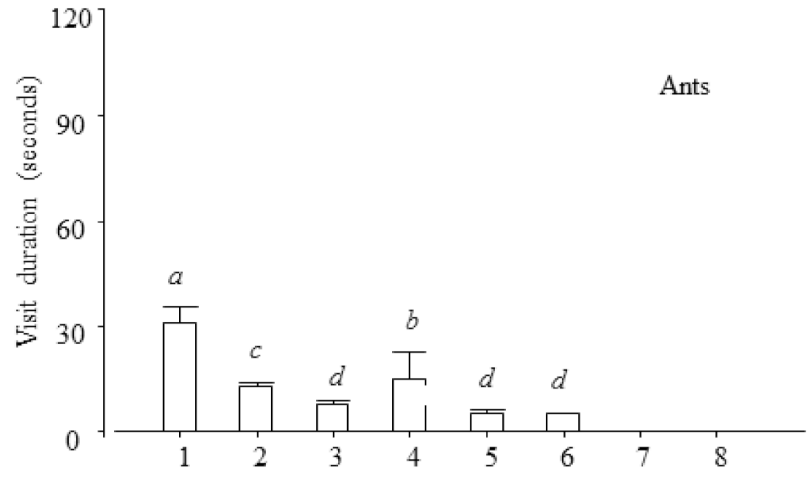

(c)

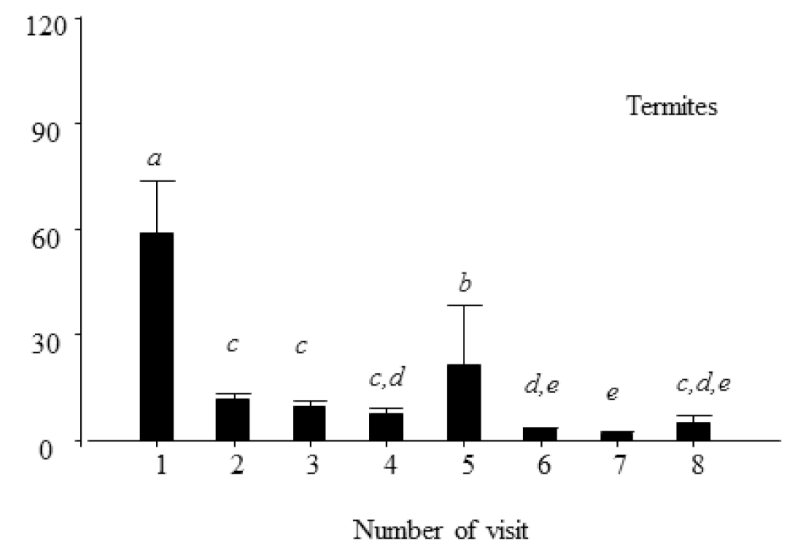

Figure 3. Average duration of each visit of a lesser anteater to the (a) control feeder, (b) feeder with ants, and (c) feeder with termites during the behavioral evaluation (10 min sessions per anteater; 3 evaluations for each animal). Different letters within each panel indicate statistical differences between the duration of the visits of the lesser anteaters to each feeder $(p<0.05)$. 
The statistical analysis indicated a highly significant difference in insect consumption (g) by the lesser anteaters $\left(\mathrm{F}_{1,32}=32.84, p<0.0001\right)$. The a posteriori test showed the following pattern: termites $0.89 \pm 0.04 \mathrm{~g}>$ ants $0.53 \pm 0.07 \mathrm{~g}$ (similar results for the percentage of insects consumed; $\mathrm{F}_{1,32}=45.79, p<0.0001$; Figure 4).

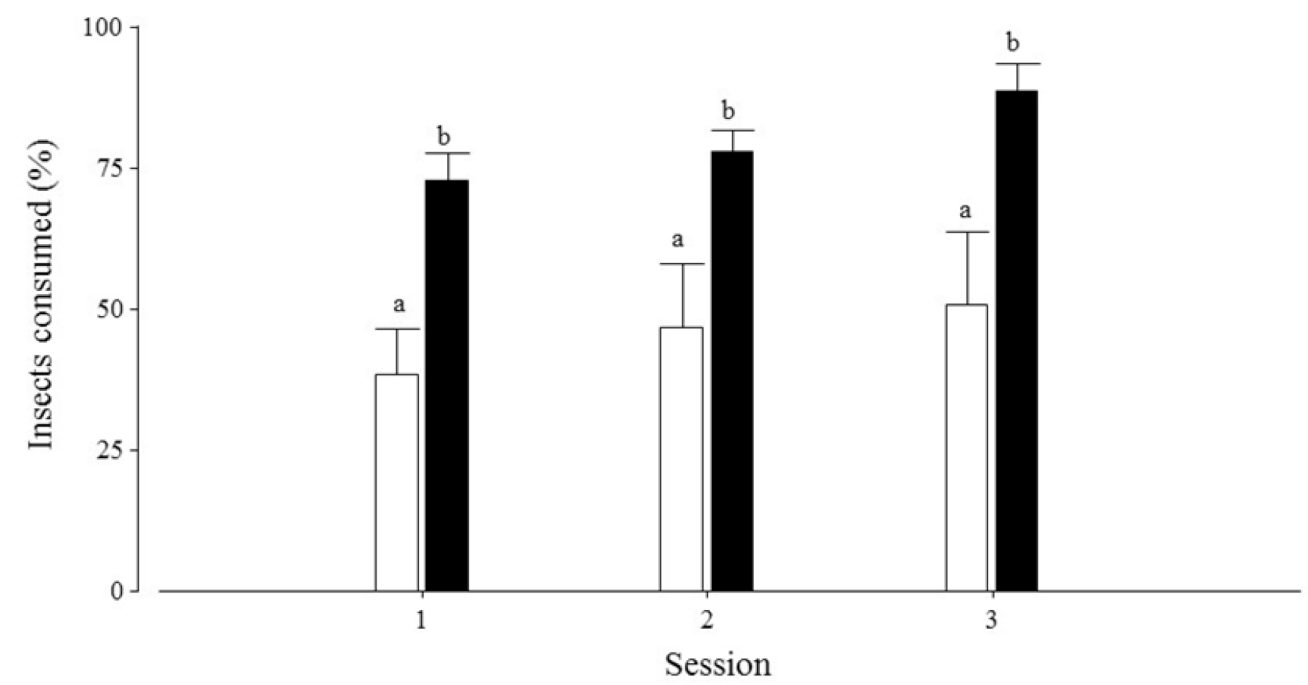

Figure 4. Percentage of insects consumed by the lesser anteaters in each of the three sessions of the behavioral evaluation. Each session lasted $10 \mathrm{~min}$. Ants are represented in white and termites in black. Different letters indicate statistical differences between the insects consumed by the lesser anteaters within each session $(p<0.05)$.

\subsection{Study 2: Objective 2}

The nutritional analyses of the insect samples showed higher values of humidity, lipids, and proteins in ants than in termites (Table 1). On the contrary, ash and carbohydrate values were higher in termites, as was the in vitro protein and carbohydrate digestibility (Table 1). On the basis of the biochemical analysis, we also calculated the energy value of the insects: samples of ants showed $2.73 \mathrm{kcal} / \mathrm{g}$, and samples of termites showed $2.17 \mathrm{kcal} / \mathrm{g}$.

Table 1. Nutritional assessment and in vitro digestibility of ant (Acromyrmex lundi) and termite samples (Cortaritermes fulviceps) offered to lesser anteaters (Tamandua tetradactyla) during the behavioral evaluations.

\begin{tabular}{ccc}
\hline Variable (\%) & \multicolumn{2}{c}{ Insects } \\
\cline { 2 - 3 } & Ants & Termites \\
\cline { 2 - 3 } Humidity & $47.37 \pm 0.52$ & $42.19 \pm 0.73$ \\
Lipids & $10.88 \pm 0.24$ & $4.08 \pm 0.43$ \\
Proteins & $29.06 \pm 0.74$ & $12.96 \pm 0.67$ \\
Ash & $7.61 \pm 0.07$ & $12.45 \pm 0.77$ \\
Carbohydrates & 14.71 & 32.20 \\
In vitro protein digestibility & $41.66 \pm 0.43$ & $97.84 \pm 1.63$ \\
In vitro carbohydrate & $50.65 \pm 0.87$ & $75.34 \pm 0.91$ \\
digestibility & &
\end{tabular}

The values are presented on a wet basis. Number of samples/insects evaluated for all variables $=2$, except for ashes $(n=1)$

\section{Discussion}

The present study reports the feeding behavior of lesser anteaters in response to the presence of their natural prey, ants (Acromyrmex lundi), and termites (Cortaritermes fulviceps). Overall, our findings clearly show that lesser anteaters reacted positively to live prey, with a difference in consumption in a space (laboratory) where the feeding behavior could be easily expressed/monitored. Surprisingly, the lesser anteaters interacted more with termites and consumed more of this insect than ants. We speculate that this response may 
be primarily related to nutritional input; however, more studies with a greater number of samples will be necessary to substantiate this hypothesis. Nevertheless, we consider that the procedure applied to test feeding preferences provides a useful protocol for further exploring feeding behavior in this species.

The relationship among the time spent with each food stimulus, the level of consumption of the different insects, the nutritional value of the insect proteins and lipids, and protein and carbohydrate in vitro digestibility could indicate that the lesser anteaters exhibited a well-adjusted feeding behavior during the evaluations. They spent more time at the termite feeders and consumed higher amounts of termites, which have low nutritional value but high protein and carbohydrate digestibility, and spent less time at the ant feeders and consumed lower amounts of ants, which have greater nutritional value but lower protein and carbohydrate digestibility. We acknowledge that termites were offered at lower frequencies than ants, which could have a novel effect on lesser anteaters' behavior. However, both ants and termites were offered at much lower frequencies than other environmental enrichment items.

Further analyses of feeding behavior responses to social insects should take into account that a predator's choice of prey depends on multiple factors other than energy input. For instance, the defensive capacity of the prey could subject predators to unpleasant experiences, thus affecting the latter's food choice decisions [42]. Since we did not detect evidence of unpleasant experience in lesser anteaters (e.g., self-scratching) when they fed on termites or ants, our results cannot be explained by prey defensiveness. Another weighty factor in the choice of prey is the organoleptic properties of the prey (e.g., olfactory cues) $[43,44]$. The higher number of first visits of lesser anteaters to feeders with termites could indicate that this prey presents more attractive cues than ants, probably associated with their pheromone emissions. This indicates that prey's organoleptic properties might be an important factor for smell-guided mammals such as lesser anteaters [1]. Furthermore, the organoleptic proprieties of insects are associated with their palatability, which could explain the values relating to the duration of visits to feeders and the consumption of insects.

In terms of the amount of time lesser anteaters spent interacting with the different social insects studied in the evaluation room, they chose to be mainly with the termites. However, we observed a similar feeding pattern for both insects: the first visit was the longest and the following ones shorter, with a second peak in duration on the fourthfifth visit. This feeding pattern is similar to that observed in wild individuals, which tend to eat insects in interrupted bouts [45]. This non-continuous feeding behavior is probably associated with a surprise-attack strategy, a behavior already mentioned for other myrmecophagous species (Myrmecophaga tridactyla [46]).

The biochemical tests demonstrated that the two insect prey differ in nutritional variables and in digestibility (tested in vitro). Oyarzun et al. [7] evaluated the nutritional characteristics of Nasutitermes sp. (Subfamily: Nasutitertitinae) as food for wild T. tetradactyla. The protein values that we found for the same termite subfamily are similar to those reported by Oyarzun et al. [7], but those of humidity, lipids, and ash differ, even though we employed the same techniques as these authors. We consider that the differences in humidity and lipid values can be attributed to the different species. In the case of ash, the difference in our study may lie in the presence of inorganic compounds in the nest: the termites we used have terrestrial habits (constructing partially underground nests composed of inorganic substrate), while those analyzed by Oyarzun et al. [7] were wood-eating termites. Normally, the ash percentage is expected to be around 5\% for insects [47], 6-10\% for wood-eating termites, and 6-60\% for soil-eating termites (e.g., C. fulviceps).

Nutritional values were lower in termite samples than in ant samples, so the preference of lesser anteaters for termites may be due to their higher in vitro digestibility. The differences in digestibility between ants and termites could be related to their different exoskeletons. Fiber analysis could help resolve this issue, but the availability of nutrients contained in ant and termite exoskeletons (carbohydrates and proteins; [48]) depends on the presence of chitinases in the digestive tract of lesser anteaters, which has still not 
been determined $[7,49]$. Thus, if lesser anteaters do not have chitinases in their digestive tracts, the nutritional values of $A$. lundi samples could be overestimated. In this sense, our study highlights the importance of studying the digestive capacities of highly specialized predators such as the lesser anteater. Though studies on in vivo digestibility (e.g., fecal content) are required, the results of our in vitro assessment should prove useful as baseline data for the better management of captive lesser anteaters. For instance, termite supply could improve lesser anteaters' welfare not only by enriching their environment through sensory stimulation (with attractive pheromones [44]) but also by improving their physical health (better digestive dynamics). This may be important for this species, considering that captive myrmecophagous mammals often present digestive problems, sometimes with deadly consequences [50,51].

Finally, we only found a few earlier reports on the feeding behavior of lesser anteaters in the wild. Lubin and Montgomery [5] pointed out that some wild Tamandua spp. individuals specialize in the consumption of termites and others in the consumption of ants. It is clearly difficult to determine selectivity in T. tetradactyla, especially in the wild, largely because of the remarkable heterogeneity of their insect prey, its availability, defense strategies, etc. [2,22,52]. Addressing Tamandua tetradactyla-Acromyrmex lundi and Cortaritermes fulviceps interaction under a controlled situation could lead to an experimental model to study the feeding behavior of a highly specialized anteater species.

\section{Conclusions}

Under the laboratory conditions of this study, our hypothesis was not disproven, indicating that the characteristics of $A$. lundi and C. fulviceps affected the feeding behavior of lesser anteaters. We demonstrated that:

- Lesser anteaters spent more time at feeders with termites (C. fulviceps) than at feeders with ants (A. lundi) and consumed more termites than ants, showing a similar pattern of interaction during consumption;

- The ants and termites analyzed presented different values of humidity, protein, ash, lipids, and in vitro protein and carbohydrate digestibility. The calculation of caloric content of termites indicated lower energy values than ants but higher digestibility of proteins and carbohydrates.

Supplementary Materials: The following are available online at https://www.mdpi.com/article/ 10.3390/jzbg3010002/s1, Table S1: Timeline of lesser anteater behavioral evaluations; Figure S1: diagram of evaluation room for each zone in novel environmental evaluation; Figure S2: Cumulative proportions of the location register of the lesser anteaters during the novel environment evaluation; Figure S3: Evaluation room zones during odor discrimination evaluation; Figure S4: Location register (counting) of the lesser anteaters in the olfactory zone during the odor discrimination evaluation; Figure S5: Respiratory frequency (registers/minute) in the lesser anteaters during novel environmental and food stimuli evaluations.

Author Contributions: Conceptualization, V.Z., J.R.M. and J.M.B.; methodology, V.Z., J.R.M., L.G.A.L., D.P.V. and J.M.B.; validation, V.Z., J.R.M., L.G.A.L. and J.M.B.; formal analysis, V.Z., J.R.M. and J.M.B.; investigation, V.Z., J.R.M. and J.M.B.; resources, J.R.M. and J.M.B.; writing — original draft preparation, V.Z., J.R.M. and J.M.B.; writing—review and editing V.Z. and J.M.B.; funding acquisition, J.M.B. All authors have read and agreed to the published version of the manuscript.

Funding: This research was funded by the Argentinean Ministry of Science, Technology and Productive Innovation, grant number BID.PICT.2014.2642, 2014.

Institutional Review Board Statement: Prior to implementation of the experimental design, studies with zoo-housed lesser anteaters were evaluated and approved by the Bioethics and Laboratory Animal Commission in accordance with the Annex to the Regulation of "Care and Use of Laboratory Animals" (IIBYT/CONICET and FCEFyN-UNC; on 9 April 2015). The study was conducted in accordance with the CONICET Ethics Committee (Resolution 1047 Annex II, 2005), the Argentinean National Law of Animal Protection ( $\left.\mathrm{N}^{\circ} 14346\right)$, and the guidelines of the Declaration of Helsinki. We 
provided all lesser anteaters with suitable housing and husbandry in this study and took into account relevant current literature to ensure animal welfare $[1,18,30]$.

Informed Consent Statement: Not applicable.

Data Availability Statement: The data presented in this study are available upon request from the corresponding author.

Acknowledgments: The authors would like to thank Parque de la Biodiversidad staff (former Cordoba Zoo, renamed by the local government in December 2020) for their assistance and collaboration during the study.

Conflicts of Interest: The authors declare no conflict of interest.

\section{References}

1. Hayssen, V. Tamandua tetradactyla (Pilosa: Myrmecophagidae). Mamm. Species 2011, 43, 64-74. [CrossRef]

2. Montgomery, G.G. Movements, Foraging and Food Habits of the Four Extant Species of Neotropical Vermilinguas (Mammalia: Myrmecophagidae). In The Evolution and Ecology of Armadillos, Sloths, and Vermilinguas; Montgomery, G.G., Ed.; Smithsonian Institution Press: Washington, DC, USA, 1985; pp. 365-377, ISBN 10: 0874746493.

3. Wetzel, R.M. The Identification and Distribution of Recent Xenarthra (= Edentata). In The Evolution and Ecology of Armadillos, Sloths, and Vermilinguas; Mongomery, G.G., Ed.; Smithsonian Institution Press: Washington, DC, USA, 1985; pp. 5-21, ISBN 10 : 0874746493.

4. Camilo-Alves, C.D.S.E.P.; Mourão, G.D.M. Responses of a Specialized Insectivorous Mammal (Myrmecophaga tridactyla) to Variation in Ambient Temperature. Biotropica 2006, 38, 52-56. [CrossRef]

5. Lubin, Y.D.; Montgomery, G.G. Defenses of Nasutitermes termites (Isoptera, Termitidae) against Tamandua anteaters (Edentata, Myrmecophagidae). Biotropica 1981, 13, 66-76. [CrossRef]

6. Sandoval-Gómez, V.E.; Ramérez-Chaves, H.E.; Marín, D. Registros de hormigas y termitas presentes en la dieta de osos hormigueros (Mammalia: Myrmecophagidae) en tres localidades de Colombia. Edentata 2012, 13, 1-9. [CrossRef]

7. Oyarzun, S.E.; Crawshaw, G.J.; Valdes, E.V. Nutrition of the tamandua: I. Nutrient composition of termites (Nasutitermes spp.) and stomach contents from wild tamanduas (Tamandua tetradactyla). Zoo Biol. 1996, 15, 509-524. [CrossRef]

8. Torres, R.; Monguillot, J.; Bruno, G.; Michelutti, P.; Ponce, A. Ampliación del límite austral de la distribución del oso melero (Tamandua tetradactyla) en la Argentina. Not. Faun. 2009, 39, 1-5.

9. Tamburini, D. Orden Cingulata. In Mamíferos de Córdoba y su Estado de Conservación; Torres, R., Tamburini, D., Eds.; Editorial de la Universidad Nacional de Córdoba: Cordoba, Argentina, 2018; pp. 87-111, ISBN 978-987-707-084-2.

10. Superina, M.; Abba, A.M.; Vizcaíno, S.F. Orden Pilosa. In Libro Rojo de los Mamíferos de Argentina; Ojeda, R.A., Chillo, V., Díaz Isenrath, G., Eds.; Sociedad Argentina para el Estudio de los Mamíferos: Buenos Aires, Argentina, 2012; pp. 59-60, ISBN 987-987-98497-2-9.

11. Miranda, F.; Fallabrino, A.; Arteaga, M.; Tirira, D.G.; Meritt, D.A.; Superina, M. Tamandua tetradactyla. The IUCN Red List of Threatened Species 2014: E.T21350A47442916. Available online: https:/ / www.iucnredlist.org/ (accessed on 20 October 2020).

12. Moore, B.D.; Marsh, K.J.; Wallis, I.R.; Foley, W.J. Taught by animals: How understanding diet selection leads to better zoo diets. Int. Zoo. Yearb. 2005, 39, 43-61. [CrossRef]

13. Morgan, K.N.; Tromborg, C.T. Sources of stress in captivity. Appl. Anim. Behav. Sci. 2007, 102, 262-302. [CrossRef]

14. Aguilar, R.F.; Superina, M. Xenarthra. In Fowler's Zoo and Wild Animal Medicine; Miller, R.E., Fowler, M.E., Eds.; Elsevier Saunders: St. Louis, MO, USA, 2015; pp. 355-369, ISBN 978-1-4557-7397-8. [CrossRef]

15. Ward, A.M.; Crisse, S.D.; Cassaro, K.; Frank, E. Formulating Diets for Tamanduas (T. tetradactyla) in Brazilian Zoos. In Proceedings of the First Annual Conference of the Nutrition Advisory Group of the American Zoo and Aquarium Association, Toronto, ON, Canada, 1-2 May 1995; Dierenfeld, E., Atkinson, J., Valdes, E.V., Eds.; Metro Toronto Zoo and the University of Guelph: Toronto, ON, Canada, 1995.

16. Morford, S.; Meyers, M.A. Giant anteater (Myrmecophaga tridactyla) diet survey. Edentata 2003, 5, $20-24$.

17. Ruiz, D.; Tello, M. Nutrición y Alimentación en la Rehabilitación de Vermilinguas y Estrategias Nutricionales Pre-Liberación. In Manual de Rehabilitación de Hormigueros de Colombia; Rojano, C., Miranda, L., Ávila, R., Eds.; Fundación Cunaguaro, Geopark Colombia S.A.S, Corporinoquía: El Yopal, Columbia, 2014; pp. 69-83.

18. Eguizábal, G.V.; Palme, R.; Villarreal, D.; Dal Borgo, C.; Di Rienzo, J.A.; Busso, J.M. Assessment of adrenocortical activity and behavior of the collared anteater (Tamandua tetradactyla) in response to food-based environmental enrichment. Zoo Biol. 2013, 32, 632-640. [CrossRef]

19. Neto, G.D.S.F.; Barros, A.C.; Sobroza, T.V.; Neves, P.U.C.; Phillips, M.J.; Guimarães, E.F. Period of the day and food-based enrichment affect behaviour activity of Tamandua tetradactyla in captivity? Pesqui. Ensino Cienc. Exatas Nat. 2020, 4, e1498. [CrossRef]

20. Hölldobler, B.; Wilson, E.O. The Ants; Harvard Press: Cambridge, MA, USA, 1990; ISBN 978-3-540-52092-4.

21. Torales, G.J.; Laffont, E.R.; Godoy, M.C.; Coronel, J.M.; Arbino, M.O. Update on taxonomy and distribution of Isoptera from Argentina. Sociobiology 2005, 45, 853-886.

22. Borror, D.J.; Triplehorn, C.A.; Johnson, N. An Introduction to the Study of Insects, 6th ed.; Holt Rinehart and Winston Saunders College Publishing: Philadelphia, PA, USA, 1989; ISBN 0-03-025397-7. 
23. Ali, M.F.; Morgan, E.D. Chemical communication in insect communities: A guide to insect pheromones with special emphasis on social insects. Biol. Rev. 1990, 65, 227-247. [CrossRef]

24. Redford, K.H. Mammalian Myrmecophagy: Feeding, Foraging and Food Preference. Ph.D. Thesis, Harvard University, Cambridge, MA, USA, 1983.

25. Redford, K.H.; Dorea, J.G. The nutritional value of invertebrates with emphasis on ants and termites as food for mammals. J. Zool. 1984, 203, 385-395. [CrossRef]

26. Stephens, D.W.; Krebs, J.R. Foraging Theory; Princeton University Press: Princeton, NJ, USA, 1986. [CrossRef]

27. Watters, J.V.; Krebs, B.L.; Eschmann, C.L. Assessing Animal Welfare with Behavior: Onward with Caution. J. Zool. Bot. Gard. 2021, 2, 75-87. [CrossRef]

28. Eguizábal, G.V.; Palme, R.; Superina, M.; Asencio, C.J.; García Capocasa, M.C.; Busso, J.M. Characterization and correlations of behavioral and adrenocortical activities of zoo-housed lesser anteaters (Tamandua tetradactyla). Zoo Biol. 2019, 38, 334-342. [CrossRef]

29. Chiapero, F.; Ferrari, H.R.; Prieto, M.V.; Garcia Capocasa, M.C.; Busso, J.M. Multivariate analyses of the activity pattern and behavior of the lesser anteater on open and closed days at Córdoba Zoo, Argentina. J. Appl. Anim. Welf. Sci. 2021, 24, 83-97. [CrossRef]

30. Mellor, D.J.; Beausoleil, N.J. Extending the 'Five Domains' model for animal welfare assessment to incorporate positive welfare states. Anim. Welf. 2015, 24, 241-253. [CrossRef]

31. Superina, M.; Miranda, F.; Plese, T. Maintenance of Xenarthra in Captivity. In The Biology of the Xenarthra; Vizcaino, S.F., Loughry, W.J., Eds.; University Press of Florida: Gainesville, FL, USA, 2008; pp. 232-243, ISBN 9780813031651.

32. Dierenfeld, E.S.; Graffam, W.S. Manual de Nutrición y Dietas para Animales Silvestres en Cautiverio (Ejemplos para América Latina); ZCOG Zoo Conservation Outreach Group: New Orleans, LA, USA, 1996; pp. 42-43.

33. AOAC. Official Methods of Analysis, 17th ed.; Association of Official Analytical Chemists International: Gaithersburg, MD, USA, 2000.

34. Berg, J.M.; Tymoczko, J.L.; Stryer, L. Biochemistry, 5th ed.; W.H. Freeman and Company: New York, NY, USA, 2002; ISBN-10: 0-7167-3051-0.

35. Boisen, S.; Fernández, J.A. Prediction of the total tract digestibility of energy in feedstuffs and pig diets by in vitro analyses. Anim. Feed Sci. Technol. 1997, 68, 277-286. [CrossRef]

36. Gull, J.M.; Stahl, M.; Osmann, C.; Ortmann, S.; Kreuzer, M.; Hatt, J.M.; Clauss, M. Digestive physiology of captive giant anteaters (Myrmecophaga tridactyla): Determinants of faecal dry matter content. J. Anim. Physiol. Anim. Nutr. 2015, 99, 565-576. [CrossRef]

37. Lin, M.F.; Chang, C.Y.; Yang, C.W.; Dierenfeld, E.S. Aspects of digestive anatomy, feed intake and digestion in the Chinese pangolin (Manis pentadactyla) at Taipei Zoo. Zoo Biol. 2015, 34, 262-270. [CrossRef] [PubMed]

38. Dierick, N.; Vervaeke, I.; Decuypere, J.; Henderickx, H. Protein Digestion in Pig Measured In Vivo and In Vitro. In Proceedings of the Third International Seminar on the Digestive Physiology in the Pig, Copenhagen, Denmark, 16-18 May 1985; Just, A. Jorgensen, H., Fernández, J.A., Eds.; National Institute of Animal Science: Copenhagen, Denmark, 1985; pp. 329-332. Available online: https://agris.fao.org/agris-search/search.do?recordID=DK8620175 (accessed on 24 December 2021).

39. Loewus, F.A. Improvement in anthrone method for determination of carbohydrates. Anal. Chem. 1952, 24, 219. [CrossRef]

40. Mangeaud, A.; Videla, M. Looking for the lost independence: Using Mixed Generalized Linear Models in choice tests. Ecol. Austral. 2005, 15, 199-206.

41. Di Rienzo, J.A.; Casanoves, F.; Balzarini, M.G.; Gonzalez, L.; Tablada, M.; Robledo, C.W. Infostat Versión 2019; Grupo InfoStat, FCA, Universidad Nacional de Córdoba: Córdoba, Argentina, 2019.

42. Bateson, M. Mechanisms of decision-making and the interpretation of choice tests. Anim. Welf. 2004, 13, S115-S120.

43. Warburton, H.; Mason, G. Is out of sight out of mind? The effects of resource cues on motivation in mink, Mustela vison. Anim. Behav. 2003, 65, 755-762. [CrossRef]

44. Wells, D.L. Sensory stimulation as environmental enrichment for captive animals: A review. Appl. Anim. Behav. Sci. 2009, 118, 1-11. [CrossRef]

45. Lubin, Y.D.; Montgomery, G.G.; Young, O.P. Food resources of anteaters (Edentata: Myrmecophagidae) I. A year's census of arboreal nests of ants and termites on Barro Colorado Island, Panama Canal Zone. Biotropica 1977, 9, 26-34. [CrossRef]

46. Redford, K.H. Feeding and food preference in captive and wild giant anteater (Myrmecophaga tridactyla). J. Zool. 1985, 205, 559-572. [CrossRef]

47. Bell, G.P. Birds and mammals on an insect diet: A primer on diet composition analysis in relation to ecological energetics. Stud. Avian Biol. 1990, 13, 416-422.

48. Allen, M.E. Nutritional Aspects of Insectivory. Ph.D. Dissertation, Michigan State University, East Lansing, MI, USA, 1989. Available online: https:/ / d.lib.msu.edu/etd/16494 (accessed on 20 October 2020).

49. Emerling, C.A.; Delsuc, F.; Nachman, M.W. Chitinase genes (CHIAs) provide genomic footprints of a post-Cretaceous dietary radiation in placental mammals. Sci. Adv. 2018, 4, eaar6478. [CrossRef]

50. Diniz, L.S.M.; Costa, E.O.; Oliveira, P.M.A. Clinical disorders observed in anteaters (Myrmecophagidae, Edentata) in captivity. Vet. Res. Commun. 1995, 19, 409-415. [CrossRef] 
51. Arenales, A.; Gardiner, C.H.; Miranda, F.R.; Dutra, K.S.; Oliveira, A.R.; Mol, J.P.; Texeira Da Costa, E.L.M.; Tinoco, H.P.; Coelho, C.M.; Silva, R.O.S.; et al. Pathology of Free-Ranging and Captive Brazilian Anteaters. J. Comp. Pathol. 2020, 180, 55-68. [CrossRef]

52. Kaspari, M.; Alonso, L.; O’Donnell, S. Three energy variables predict ant abundance at a geographical scale. Proc. R. Soc. Lond. B Biol. Sci. 2000, 267, 485-489. [CrossRef] 